\title{
Expression of hpal Gene Encoding a Bacterial Harpin Protein in Xanthomonas oryzae pv. oryzae Enhances Disease Resistance to Both Fungal and Bacterial Pathogens in Rice and Arabidopsis
}

\author{
Min-Seon Choi ${ }^{1,2,3}$, Sunggi Heu ${ }^{2}$, Nam-Chon Paek ${ }^{3}$, Hee-Jong Koh ${ }^{3}$, Jung-Sook Lee ${ }^{4 \dagger}$ and Chang-Sik Oh ${ }^{1 *}$ \\ ${ }^{1}$ Department of Horticultural Biotechnology and Institute of Life Sciences \& Resources, Kyung Hee University, Yongin 446-701, \\ Korea \\ ${ }^{2}$ Microbial Safety Division, National Academy of Agricultural Science, Rural Development Administration, Suwon 441-707, \\ Korea \\ ${ }^{3}$ Department of Plant Science, Seoul National University, Seoul 151-921, Korea \\ ${ }^{4}$ Genomics Division, National Academy of Agricultural Science, Rural Development Administration, Suwon 441-707, Korea \\ (Received on September 4, 2012; Revised on September 23, 2012; Accepted on September 23, 2012)
}

\begin{abstract}
Xanthomonas oryzae pv. oryzae causing bacterial leaf blight disease in rice produces and secretes Hpa1 protein that belongs to harpin protein family. Previously it was reported that $\mathrm{Hpa} 1$ induced defense responses when it was produced in tobacco. In this study, we expressed $h p a 1$ gene in rice and Arabidopsis to examine the effects of $\mathrm{Hpa} 1$ expression on disease resistance to both fungal and bacterial pathogens. Expression of hpal gene in rice enhanced disease resistance to both $X$. oryzae pv. oryzae and Magnaporthe grisea. Interestingly, individual transgenic rice plants could be divided into four groups, depending on responses to both pathogens. hpal expression in Arabidopsis also enhanced disease resistance to both Botrytis cineria and Xanthomonas campestris pv. campestris. To examine genes that are upregulated in the transgenic rice plants after inoculation with $X$. oryzae pv. oryzae, known defense-related genes were assessed, and also microarray analysis with the Rice $5 \mathrm{~K}$ DNA chip was performed. Interestingly, expression of $O$ sACS1 gene, which was found as the gene that showed the highest induction, was induced earlier and stronger than that in the wild type plant. These results indicate that hpal expression in the diverse plant species, including monocot and dicot, can enhance disease resistance to both fungal and bacterial plant pathogens.
\end{abstract}

Keywords : bacterial leaf blight pathogen, defense response, harpin, OsACS1 gene, rice blast pathogen

\footnotetext{
*Corresponding author.

Phone)+82-31-201-2678, FAX) +82-31-204-8116

E-mail)co35@khu.ac.kr

Current address: Foundation of Agri. Tech. Commercialization \& Transfer, Suwon 441-857, Korea
}

Harpins are heat-stable and glycine-rich proteins, but have few cysteine and aromatic amino acids (Beer et al., 1993). They are secreted from bacteria through type III secretion system and are known to be located at intercellular space of plant tissues (Alfano and Collmer, 1997). Harpin proteins have been identified from diverse Gram-negative plantpathogenic bacteria such as Erwinia amylovora (Kim and Beer, 1998; Wei et al., 1992), Pseudomonas syringae (Charkowski et al., 1998; He et al., 1993; Kvitko et al., 2007), Ralstonia solanacearum (Arlat et al., 1994), and Xanthomonas species (Kim et al., 2003; Noel et al., 2002; Zhu et al., 2000). For example, Hpa1 is the harpin protein that is produced and secreted from $X$. oryzae pv. oryzae causing bacterial leaf blight in rice (Zhu et al., 2000). It is a $13-\mathrm{kDa}$ glycine-rich protein carrying two coiled-coil regions in its $\mathrm{N}$ - and C-termini (Ji et al., 2011). Its expression is regulated by $\operatorname{HrpB}$, a regulatory protein that controls expression of other hrp (hypersensitive response and pathogenicity) genes in $X$. oryzae pv. oryzae by directly binding their promoters with PIP boxes (Zhu et al., 2000). Hpal orthologs have been identified from other Xanthomonas species such as HpaG from $X$. axonopodis pv. glycines and XopA from $X$. campestris pv. vesicatoria (Kim et al., 2003; Noel et al., 2002).

Originally harpin proteins, including $\mathrm{HrpN}$ of E. amylovora were identified as elicitors of hypersensitive response (HR) in tobacco (Wei et al., 1992). HR represents the rapid localized cell death that occurs at the infection sites in plants (Keen, 1990). This is one of strong disease resistance phenotypes to plant pathogens. It has been reported that several harpin proteins, including Hpal of $X$. oryzae pv. oryzae and its ortholog HpaG of $X$. axonopodis pv. glycines, but not XopA of $X$. campestris pv. vesicatoria, induce strong HR phenotypes, when they are partially purified and infiltrated into tobacco leaves (Kim et al., 2003). This 
implies that harpin proteins function outside the plant cells to trigger HR, consistent with evidence that harpin proteins are secreted from bacterial pathogens and targeted outside the plant cells (Perino et al., 1999).

In addition to HR, defense responses without HR induction in plants can be initiated by recognition of pathogen factors, and this recognition triggers increase of the internal level of signaling molecules like salicylic acid (SA), nitric oxide (NO), reactive oxygen species (ROS), jasmonic acid (JA) and ethylene (Hammond-Kosack and Parker, 2003). These signaling molecules activate downstream defense signal transduction pathways, resulting in induction of diverse defense-related genes such as pathogenesis-related (PR) genes. SA is the key molecule for induction of SAR, which confers disease resistance to biotropic pathogens such as Hyaloperonospora arabidopsidis (formerly Peronospora parasitica) and P. syringae pv. tomato in Arabidopsis (Durrant and Dong, 2004). The SA signaling cascade for systemic acquired resistance (SAR) induction requires NPR1 (also known as NIM1) to activate the expression of PR1 gene (Cao et al., 1994; Delaney et al., 1995). On the other hands, JA and ethylene are crucial molecules for SAindependent defense responses, which are important for resistance to necrotropic pathogens like $X$. campestris pv. campestris and Botrytis cinerea in Arabidopsis (Thomma et al., 1998; Thomma et al., 1999). JA is also related with plant's wound responses and defense against insects (Reymond et al., 2000).

Interestingly, when harpin genes are expressed and may be located inside plant cells, they do not seem to trigger $\mathrm{HR}$, but instead confer defense responses to diverse plant pathogens including fungi, oomycetes, bacteria, and viruses. For examples, it was previously shown that hrpN expression under Cauliflower mosaic virus (CaMV) 35S promoter in Arabidopsis induces expression of PRl gene by activating SAR (Dong et al., 1999), and also that hpal expression under $35 \mathrm{~S}$ promoter in tobacco induces expression of defense-related genes such as $P R-1 a$ and $P R-1 b$ in a NPR1-dependent manner without HR phenotype (Peng et al., 2004). Recently, transcriptome analysis after hpal expression in cotton showed that genes responsible for multiple defense signaling pathways are constitutively expressed (Miao et al., 2010).

In this study, hpal gene of $X$. oryzae pv. oryzae strain KXO85 was transformed in rice and Arabidopsis and was expressed under a constitutive promoter (actin1 promoter in rice or CaMV $35 \mathrm{~S}$ promoter in Arabidopsis). In these transgenic rice and Arabidopsis, the effect of hpal expression on disease resistance to both bacterial and fungal pathogens was examined. Here, we show that expression of hpal gene increases disease resistance to both bacterial and fungal pathogens in both rice and Arabidopsis, and ex- pression of rice OsACS1 gene was induced in the hpaltransformed rice plant.

\section{Materials and Methods}

Bacterial and fungal strains and growth conditions. Escherichia coli strains, DH5 $\alpha$ and Top10 (Invitrogen, USA) and Agrobacterium tumefaciens strains GV3010 and LBA4404 were grown in LB medium at $37^{\circ} \mathrm{C}$ and $28^{\circ} \mathrm{C}$, respectively. $X$. oryzae pv. oryzae strain $\mathrm{KXO} 85$ and $X$. campestris pv. campestris strain $1366 \mathrm{R}$ were cultivated at $28^{\circ} \mathrm{C}$ in peptone-sucrose agar (PSA; $10 \mathrm{~g}$ Bacto-peptone, $10 \mathrm{~g}$ sucrose, $1 \mathrm{~g}$ Na-glutamate, $15 \mathrm{~g}$ agar/l) or LB broth. Antibiotics were used as follows: rifampicin (Rif), $50 \mu \mathrm{g}$ / $\mathrm{ml}$; kanamycin (Km), $50 \mu \mathrm{g} / \mathrm{ml}$; ampicillin (Ap), $50 \mu \mathrm{g} / \mathrm{ml}$. The fungal pathogens, Magnaporthe grisea and Borytis cineria were grown at $28^{\circ} \mathrm{C}$ on rice sucrose agar medium (20 g rice bran, $20 \mathrm{~g}$ sucrose, $20 \mathrm{~g}$ agar/l) and potato dextrose agar medium (39 g/l, Difco, USA), respectively.

Gene constructs for plant transformation. To generate hpal gene constructs for plant transformation, $0.42-\mathrm{kb}$ DNA fragment carrying the full length hpal gene was amplified by PCR with the cosmid pJG3 containing 26-kb genomic DNA of $X$. oryzae pv. oryzae strain KXO85 as a template and two gene-specific primers, the forward primer (5'-GGATCCATGAATTCTTTGAACACAC-3' with BamHI site) and the reverse primer (5'-TCTAGATGGCCGGTAG GGGCG-3' with $X b a$ I site). The PCR product was inserted into pCR2.1 (Invitrogen, USA) to produce pMS-hpaTOPO. The hpal gene from pMS-hpaTOPO was transferred into the BamHI-XbaI digested pBluescriptII $\mathrm{KS}(+)$ vector to produce pMS-hpal.

For rice transformation, a $1.3-\mathrm{kb}$ act 1 promoter was cut out from the parent plasmid (McElroy et al., 1990) and the fragment was blunt-ended by the Klenow reaction. This fragment was ligated into SmaI-digested pMS-hpal plasmid to produce pMS-pact1-hpal. After the pSBG-MAR vector (Jang et al., 1999) was digested with XhoI and blunt-ended by the Klenow reaction, it was digested with $X b a \mathrm{I}$ again and ligated with the $1.75-\mathrm{kb} E c o \mathrm{RV}-X b a \mathrm{I}$ DNA fragment, including the actl promoter and hpal gene from pMSpact1-hpal, to produce pSBG-pact1-hpal. (Fig. 1A). The pSBG-pact1-hpal was introduced to $A$. tumefaciens strain LBA4404 for rice transformation.

For Arabidopsis transformation, a 0.85-kb HindIII-Bam HI DNA fragment of pBI221 (Clontech, USA), including the $35 \mathrm{~S}$ promoter, was ligated into HindIII-BamHI digested pMShpal vector to produce pMS-p35S::hpal. Then, p35S::hpal in this plasmid was transferred into pCAMBIA2301 vector (CAMBIA, Australia) to generate pCAM-p35S::hpal (Fig. 3A). The pCAM-p35S::hpal was introduced to A. tume- 
faciens strain GV3101.

Agrobacterium-mediated transformation in rice and Arabidopsis. For rice transformation, Agrobacterium strain LBA4404 containing pSBG-pact1-hpal was used to transform Nagdong rice calli, according to the method described by Hiei et al. (1994). Transgenic plants overexpressing hpal gene were regenerated from transformed calli showing resistance to phosphinothricin. Then, they were transplanted to soil in greenhouse and their herbicide resistance was tested with $0.6 \%$ solution of Basta ${ }^{\circledR}$ (Misung chemicals, Korea).

For Arabidopsis transformation, A. tumefaciens strain GV3010 containing pCAM-p35S::hpal construct was grown for $24 \mathrm{~h}$ at $28^{\circ} \mathrm{C}$ in LB medium supplemented with kanamycin. $100 \mu$ of pre-culture was used to inoculate fresh LB media $(100 \mathrm{ml})$ with the same antibiotic. Cells grown for 2 days were collected by centrifugation and resuspended with transformation medium (5\% sucrose and $0.05 \%$ Silwet L77) (Clough and Bent, 1998), and its concentration was adjusted to $\mathrm{OD}_{600}=1.0$. Transformation was done by floral dip method in A. thaliana ecotype Columbia (Col-0), which was grown at the greenhouse (Clough and Bent, 1998). After dipping, the plants were placed on a plastic flat and covered with a plastic dome to maintain humidity. The dome was removed next day. The putative transgenic Arabidopsis plants were selected by planting the seeds on a $1 / 2 \mathrm{MS}$ (half MS salts and vitamins, B5 vitamin, 2 g Pytagel/1) medium containing kanamycin $(100 \mathrm{mg} / \mathrm{l})$. After 3 weeks on the medium, the kanamycin-resistant $\mathrm{T} 1$ plants were transferred to soil and grown at the greenhouse, and they were used for disease assay and for generating T2 plants.

Pathogen inoculation. For diseases caused by Xanthomonas pathogens, $X$. oryzae pv. oryzae strain KXO18 in rice and $X$. campestris pv. campestris strain 1366R in Arabidopsis, bacteria were grown on PSA medium for 2-3 days at $28^{\circ} \mathrm{C}$, and inoculum was prepared by suspending bacterial cells in $10 \mathrm{mM} \mathrm{MgCl}$. Their final concentration was adjusted to $5 \times 10^{8} \mathrm{cfu} / \mathrm{ml}$ and $3 \times 10^{6} \mathrm{cfu} / \mathrm{ml}$, respectively. Bacterial inoculation was performed by the leaf clipping method (Kauffman et al., 1973) in rice at the maximum tillering stage and Arabidopsis at rosette growth complete stage, and lesion length was measured on three leaves 14 days after inoculation. These experiments were repeated at least twice, and 3-5 plants were used per each replicate.

For disease caused by fungal pathogen, M. grisea, the mycelium was grown on rice sucrose agar medium at $28^{\circ} \mathrm{C}$ in dark for 7 days. For spore formation, it was stressed by scraping and placed under continuous lights for 2 days. For gray mold disease caused by $B$. cineria in Arabidopsis, the fungus was grown on potato dextrose agar medium. The spores were collected by scraping with $0.05 \%$ Tween 20 and the concentration of both fungal pathogens was adjusted to $10^{5} \mathrm{spores} / \mathrm{ml}$. Inoculation was carried out by spraying the spore suspension with an air compressor onto 3rd to 4th leaf stage rice plants and Arabidopsis at growth stage 3.7 (Boyes et al., 2001) until leaves were covered with fine droplets. Plants were incubated in a dew chamber at $28^{\circ} \mathrm{C}$ for $24 \mathrm{hr}$ and then transferred to greenhouse. Disease was measured after 6 days by estimating the relative leaf area covered with lesions. These experiments were repeated at least twice, and 3-5 plants were used per each replicate.

Total RNA isolation and RT-PCR. Total RNAs were extracted from rice leaves sampled from rice plants inoculated with $X$. oryzae pv. oryzae strain $\mathrm{KXO18}$ by using the TRIzol according to the manufacturer's manual (Invitrogen, USA). $2 \mu \mathrm{g}$ of total RNA, oligo $\mathrm{dT}_{15}$ primer, and AMV reverse transcriptase (Roche, USA) were used to synthesize cDNAs for the semi-quantitative RT-PCR. Gene-specific primers used to check expression of hpal, OsPRl (GenBank: AF306651), OsPAL (GenBank:X16099), OsCHS (GenBank: AB058397), OsPOX (GenBank:AF014467), OsPR10 (GenBank: AF395880) or actin gene (GenBank: AC092557.7) as an internal control were listed in Table 1.

Microarray analysis. Microarray experiments were performed using the Rice $5 \mathrm{~K}$ DNA chip generated at the National Institute of Agricultural Sciences and Technology (NIAST, Korea). The 4,800 unique rice cDNA clones selected from cold-treated rice cDNA library were mounted on Rice 5 K DNA chip by Generation III ArraySpotter (Amersham, USA). Cy3 and Cy5-labeled probes were prepared

Table 1. Primers used to assess expression of genes shown in Fig. 4

\begin{tabular}{|c|c|}
\hline $\begin{array}{l}\text { Target } \\
\text { genes }\end{array}$ & DNA sequences \\
\hline \multirow[t]{2}{*}{ hpal } & Forward: 5'-TGAATTCTTTGAACACACAATTCG-3 \\
\hline & Reverse: 5'-CTCGAGAGGTTGGTGCCGAGG-3' \\
\hline \multirow[t]{2}{*}{ OsPRl } & Forward: 5'-ATGGCAACCTCCAGCTTGCTAG-3' \\
\hline & Reverse: 5'-GAAGACGCCGAGGCTGTTGTC-3' \\
\hline \multirow[t]{2}{*}{ OsPAL } & Forward: 5'-GCGACATCTACGGCGTCACC-3' \\
\hline & Reverse: 5'-CTCGTTCACCTTCTTGGCGTG-3' \\
\hline \multirow[t]{2}{*}{ OsCHS } & Forward: 5'-CATCACCCACCTCGTCTTCTGC-3' \\
\hline & Reverse: 5'-GGAGGATGGTCTGGCTCGCCG-3' \\
\hline \multirow[t]{2}{*}{$O s P O X$} & Forward: 5'-CTGCTTCGTCCAAGGGTGCGAC-3' \\
\hline & Reverse: 5'-GTCCCTGAAGTTCTGGCACTGC-3' \\
\hline \multirow[t]{2}{*}{ OsPR10 } & Forward: 5'-CAGTTCAACTTCACCTCAGCCA-3' \\
\hline & Reverse: 5'-GCAAAACCAACAGGTAGATGCT-3' \\
\hline \multirow[t]{2}{*}{ Actin } & Forward: 5'-TGTCATGGTTGGAATGGGCCA-3' \\
\hline & Reverse: 5'-AGGCAGTCAGTCAGATCACGA-3' \\
\hline
\end{tabular}


from total RNA of the transgenic or non-transgenic rice leaves that were sampled at $9 \mathrm{hr}$ after inoculation with $X$. oryzae pv. oryzae strain KXO18, respectively. Briefly, 40 ug total RNA was labeled using a 3DNA Array 50 Expression Array Detection Kit (Genisphere) according to the manufacturer's protocols. Total RNA was reverse-transcribed using SuperScript III reverse transcriptase (Gibco) with RT primer containing a specially designed 3DNA capture sequence for $\mathrm{Cy} 3$ and $\mathrm{Cy} 5$ detection. Following incubation at $42^{\circ} \mathrm{C}$ for 2 hours, the reaction was stopped by adding $7 \mathrm{ul}$ of $0.5 \mathrm{M} \mathrm{NaOH} / 50 \mathrm{mM}$ EDTA, and the template RNA was degraded by incubation at $65^{\circ} \mathrm{C}$ for 10 min. The reaction solution was neutralized with $10 \mathrm{ul}$ of $1 \mathrm{M}$ Tris-HCl, pH 7.5. Two cDNA samples were combined into one tube then precipitated in ethanol. The dried sample was resuspended in water and then used for hybridization. The glass slide was placed in a sealed hybridization cassette and submerged in a $60^{\circ} \mathrm{C}$ water bath for $16-20 \mathrm{~h}$. After hybridization, the slide was washed in $2 \times \mathrm{SSC}, 0.2 \% \mathrm{SDS}$ for $15 \mathrm{~min}$ at $55^{\circ} \mathrm{C}$, then in $2 \times \mathrm{SSC}$ for $15 \mathrm{~min}$, and finally in $0.2 \times \mathrm{SSC}$ for $15 \mathrm{~min}$ at room temperature with agitation using stirring bar. The dried slide was then hybridized with the fluorescent 3DNA reagent in a $60^{\circ} \mathrm{C}$ water bath for 4 hours. After finishing 3DNA hybridization, the slide was washed as described above. Microarray slide was scanned using Axon scanner with GenePix Pro software and further analysis was performed with the GeneSpring software (Silicon Genetics, SanCarlos, CA).

Northern blotting. Total RNA $(10 \mu \mathrm{g})$ was denatured by heating at $65^{\circ} \mathrm{C}$ for $15 \mathrm{~min}$ in RNA loading dye (Ambion, USA) with $5.5 \mu \mathrm{g}$ ethidium bromide, followed by electrophoresis on $18 \%$ formaldehyde gels. The fractionated RNA was transferred to the nylon membranes (Hybond $\mathrm{N}+$, Amersham, USA) and cross-linked by irradiation with UV light. The EcoRI fragment of hpal gene and the full length of the Oryza sativa 1-aminocyclopropane-1-carboxylate synthase (OsACS1) gene were ${ }^{32} \mathrm{P}$-labeled with a random priming kit (Amersham, USA) to be used as a probe. Prehybridization was performed at $65^{\circ} \mathrm{C}$ for $30 \mathrm{~min}$ in the hybridization solution (1\% BSA, $1 \mathrm{mM}$ EDTA, $0.5 \mathrm{M}$ $\mathrm{NaPO}_{4}$ and 7\% SDS). Hybridization was performed overnight at $65^{\circ} \mathrm{C}$ in the hybridization solution added with $50 \mu \mathrm{l}$ of ${ }^{32} \mathrm{P}$-labeled probes. The membranes were washed with $2 \times \mathrm{SSC}, 0.1 \% \mathrm{SDS}$ for $15 \mathrm{~min}$ and then $1 \times \mathrm{SSC}, 0.1 \% \mathrm{SSC}$ for $15 \mathrm{~min}$ at $65^{\circ} \mathrm{C}$. The hybridized blots were exposed to X-ray films.

\section{Results and Discussion}

Generation of transgenic rice over-expressing the $h p a l$ gene. Previously, it was reported that expression of hpal gene of $X$. oryzae pv. oryzae in tobacco enhances defense responses to diverse pathogens (Peng et al., 2004). Based on this report, we tried to determine the effect of Hpal expression on disease resistance in rice and generated hpal construct for rice transformation. In this construct, hpal expression is controlled by rice actinl (act1) promoter (McElroy et al., 1990), as shown in Fig. 1A. This hpal construct was transformed into rice cultivar Nakdong, which belongs to a japonica type and is very susceptible to both bacterial leaf blight and rice blast diseases (Ahn et al., 2005a; Ahn et al., 2005b; Koh et al., 1987). Total 56 of T0 transgenic lines resistant to Basta $^{\circledR}$ treatment were generated. First, regardless of hpal expression, most of these regenerated plants (53 out of 56 lines) displayed normal phenotypes (data not shown), indicating that overexpression of hpal does not affect rice growth and development, as did not in tobacco (Peng et al., 2004). Then, we checked expression of hpal gene in these transgenic lines. 51 of $53 \mathrm{~T} 0$ transgenic lines showed certain level of hpal expression, but two lines did not (Fig. 1B). Fig. 1B shows hpal expression determined by northern blotting with hpal gene as a probe in 20 representatives of T0 transgenic lines.

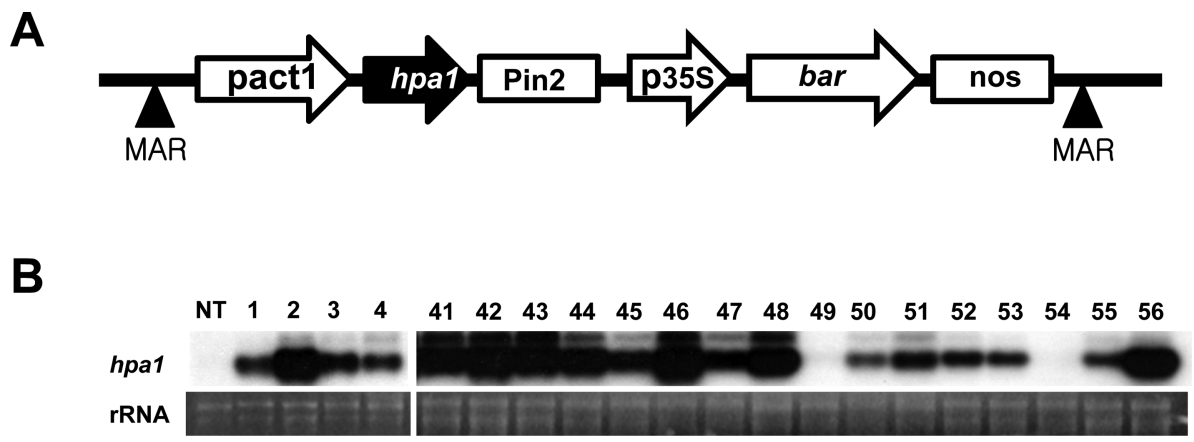

Fig. 1. hpal expression in the transgenic rice. (A) Genetic structure of T-DNA region carrying hpal gene under actin promoter (pact1). Arrows indicate direction of transcription. p35S, CaMV 35S promoter; Pin2 and nos, transcriptional terminators, MAR, matrix attachment region. (B) hpal expression in 20 representatives of T0 transgenic rice by northern blot analysis with hapl gene as a probe. Ribosomal RNAs (rRNA) were shown by ethidium bromide staining as loading controls. NT, non-transformed. 
Table 2. Grouping of total $53 \mathrm{~T} 0$ transgenic rice based on response to $X$. oryzae pv. oryzae (BLB) and M. grisea (RB)

\begin{tabular}{|c|c|c|c|}
\hline $\mathrm{RB}_{\mathrm{BLB}}$ & $\mathrm{R}$ & S & Total \\
\hline $\mathrm{R}$ & 30 & 3 & $33(62 \%)$ \\
\hline S & 15 & 5 & $20(38 \%)$ \\
\hline Total & $45(85 \%)$ & $8(15 \%)$ & $53(100 \%)$ \\
\hline
\end{tabular}

$\mathrm{R}$, resistant; $\mathrm{S}$, susceptible

Disease response in transgenic rice plants harboring pact $1:$ hpal to both bacterial and fungal plant pathogens. We investigated whether the transgenic rice lines displayed disease resistance to bacterial and fungal pathogens. For the disease response to bacterial pathogen, 53 of T0 transgenic rice showing normal growth were inoculated with $X$. oryzae pv. oryzae KXO18 using the leaf clipping method. Lesion length was measured on three leaves at 14 days after inoculation, and the grouping was done as $\mathrm{R}$ (resistant) or S (susceptible) based on more than $50 \%$ reduction of lesion length relative to that of untransformed rice plants as the control. Among 53 T0 lines, 45 lines (85\%) showed resistance to $X$. oryzae pv. oryzae (Table 2 ). For the response to the fungal pathogen, M. grisea, transgenic plants were inoculated with spore solution by spraying, and disease were observed at third to fourth leaf stage of T0 plants. Disease severity was scaled from 0 to 9 , as described (IRRI, 1996). Lesion scales, 0 through 3, were considered as R, and scales, 5 through 9, were considered as $\mathrm{S}$. Among 53 of T0 lines, $33(62 \%)$ showed resistance to M. grisea (Table 2).

Based on responses to both pathogens, $53 \mathrm{~T} 0$ lines can be categorized into four types, R/R, R/S, S/R, and S/S types. As shown in Table 2 and Fig. 2A, 30 of T0 lines including AP42 line showed resistance to both pathogens (R/R type). 15 of T0 lines only showed disease resistance to $X$. oryzae pv. oryzae (R/S type), while only 3 lines showed disease resistance to $M$. grisea ( $\mathrm{S} / \mathrm{R}$ type). Finally, 5 lines were susceptible to both pathogens (S/S type). Disease severity in the representative lines for each type was shown in Fig. $2 \mathrm{~A}$, and disease symptom in AP42 line belonging to R/R type, compared to the untransformed rice plants, was shown in Fig. 2B. These results indicate that expression of hpal gene in rice enhances disease resistance to both bacterial and fungal pathogens.

Harpins including Hpal protein in bacterial pathogens are secreted out from bacterial cells and targeted to intercellular space of plant tissues (Alfano and Collmer, 1997; Perino et al., 1999). In addition, when infiltrated into intercellular space of plant tissues, harpins induce the HR, which is a strong resistance response (Kim et al., 2003). This means that harpins normally function outside plant cells.
A

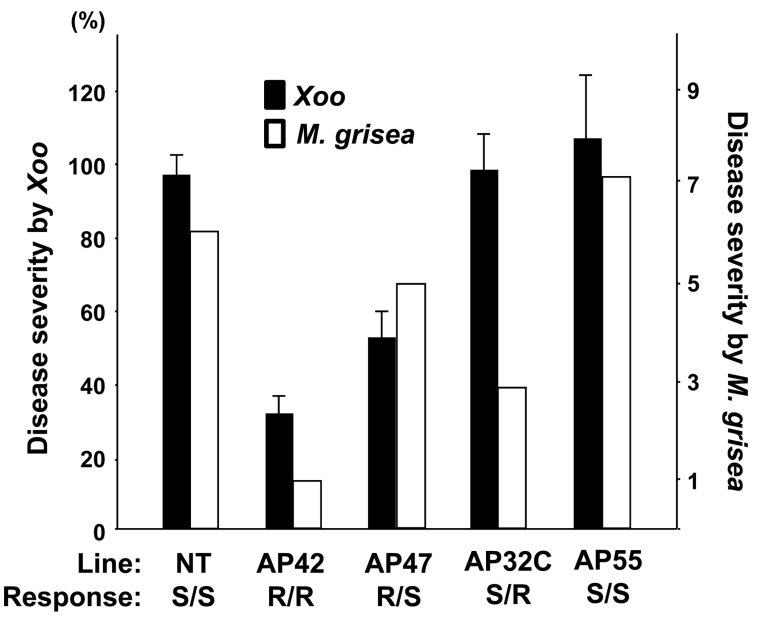

B
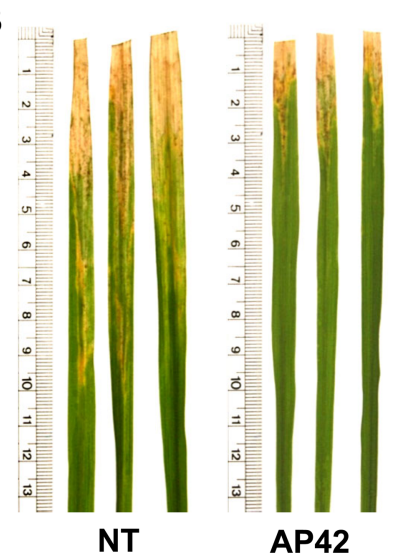

C

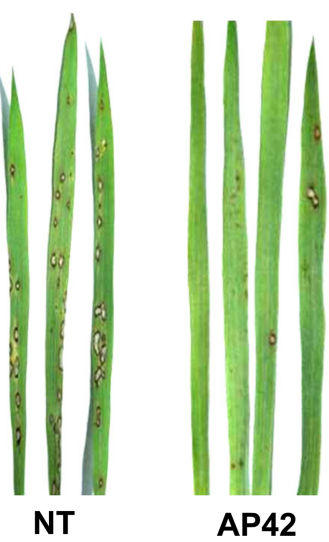

Fig. 2. Effect of hpal expression in $\mathrm{T} 0$ transgenic rice on disease resistance against plant pathogens. (A) Disease severity in four different groups of $\mathrm{T} 0$ transgenic rice by two pathogens shown in (B) and (C). NT, non-transformed; S, susceptible; R, resistant. (B) Response to $X$. oryzae pv. oryzae strain $\mathrm{KXO18}$, causing bacterial leaf blight. The top of rice leaves were cut by scissors after dipping in bacterial solution $\left(5 \times 10^{8} \mathrm{cfu} / \mathrm{ml}\right)$. Photos were taken 14 days after inoculation. AP42, T0 transgenic rice; NT, nontransformed. (C) Response to $M$. grisea, causing rice blast. Rice plants were sprayed with spore solution $\left(1 \times 10^{5}\right.$ spores $\left./ \mathrm{ml}\right)$, and photos were taken 6 days after inoculation. AP42, T0 transgenic rice; NT, non-transformed.

When hpal was expressed in plant cells, this protein is very likely located inside plant cells. Based on our study and the previous study (Peng et al., 2004), the presence of Hpal proteins inside plant cells may induce a weak disease resistance, compared to HR induction by the presence of Hpa1 proteins outside plant cells.

Disease response in transgenic Arabidopsis harboring p35S::hpal to both bacterial and fungal plant pathogens. To examine the effect of hpal expression in Arabidopsis on defense responses to plant pathogens, the full length of this gene was cloned into pCAMBIA2301 vector 
A

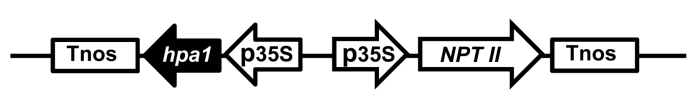

B

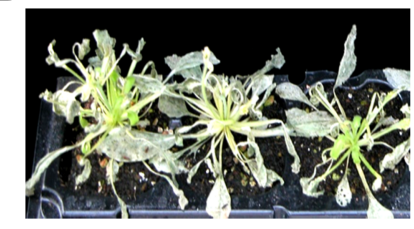

NT

C

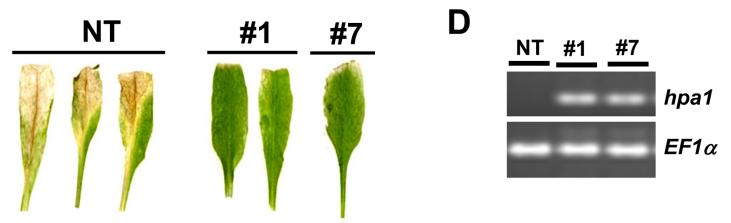

Fig. 3. Effect of hpal expression in Arabidpsis on disease resistance against two plant pathogens. (A) Genetic structure of TDNA region carrying hpal gene under CaMV 35S promoter (p35S). Arrows indicate direction of transcription. Tnos, nopaline synthase (nos) transcriptional terminator. (B) Response to $B$. cineria in T2 plants of transgenic Arabidopsis (line 7) carrying p35S::hpal. Photos were taken 6 days after spray inoculation with $1 \times 10^{5}$ spore $/ \mathrm{ml}$ of the fungus. NT, non-transformed. (C) Response to $X$. campestris pv. campestris in T2 plants of transgenic Arabidopsis (lines 1 and 7) carrying p35S::hpal. Photos were taken 14 days after inoculation with the bacterium $(\mathrm{OD}=0.03)$ by the leaf clipping method. NT, non-transformed. (D) Expression of hpal gene in transgenic Arabidopsis by RTPCR. EFla gene was used as an internal control. NT, nontransformed.

to generate pCAM-p35S::hpal construct (Fig. 3A). This construct was used for transformation in Arabidopsis ecotype Col-0 by floral dipping method. Two different plant pathogens, B. cineria and X. campestris pv. campestris, were used to determine the effect of hpal expression on defense responses in transgenic Arabidopsis. First, B. cineria fungus was inoculated by spray in 95 of T1 plants at growth stage 3.7 (Boyes et al., 2001). The survived plants were considered as resistant $(\mathrm{R})$ and the dead plants were considered as susceptible (S). 36 out of 95 T1 plants (37.9\%) showed resistance to the $B$. cineria and 59 transformants (62.1\%) were susceptible. Next, 36 transformants that are resistant to $B$. cineria were inoculated with $X$. campestris pv. campestris strain 1366R using the leaf clipping method. Plants with lesion length under $50 \%$ to the non-transformant control were considered as $\mathrm{R}$ and plants with lesion length over $50 \%$ to the non-transformant control were considered as S. Only 4 out of 36 transformants (11\%) showed resistance to the X. campestris pv. campestris strain 1366R. To exclude interference by the prior inoculation with B. cineria, 171 more T1 plants were inoculated with $X$. campestris pv. campestris strain 1366R. 28 out of 171 plants $(16 \%)$ showed resistance to this bacterium. These results indicate that Hpa1 expression in Arabidopsis enhances resistance to both pathogens, but resistance was more efficient to the fungal pathogen. Similarly, in tobacco carrying hpal gene, resistance to $R$. solanacearum was more efficient than that to Alternaria alternata (Peng et al., 2004). These indicate that difference in efficiency may be not originated from identity or types of pathogens. What causes these differences still remains to be determined.

To determine if Hpa1-mediated resistance to plant pathogens is stably inherited to the next generation, 5 different T2 transgenic Arabidopsis lines were generated from T1 plants. Two T2 lines were generated from T1 plants that showed resistance to both $B$. cineria and $X$. campestris pv. campestris (R/R type), and three lines were generated from T1 plants that showed resistance to B. cineria, but susceptible to $X$. campestris pv. campestris (R/S type). 5 plants per each line were inoculated with either $B$. cineria or $X$. campestris pv. campestris. In the case of $\mathrm{T} 2$ lines originated from R/R type T1 plants, all of 5 plants showed resistance to B. cineria (Fig. 3B). However, only 2 plants showed resistance to $X$. campestris pv. campestris (Fig. 3C). hpal gene was well expressed in these two T2 plants (Fig. 3D). In the case of $\mathrm{T} 2$ lines originated from R/S type T1 plants, 3 to 5 out of 5 plants showed resistance to $B$. cineria, but all of them showed susceptible to $X$. campestris pv. campestris. These results indicate that Hpal-mediated resistance is stably inherited to the next generation, particularly in the $\mathrm{R} /$ $\mathrm{R}$ type for B. cineria.

Expression pattern of defense-related genes in transgenic rice plants. We showed that expression of Hpal protein enhanced resistance to both bacterial and fungal pathogens in rice. To examine which defense pathway(s) might be

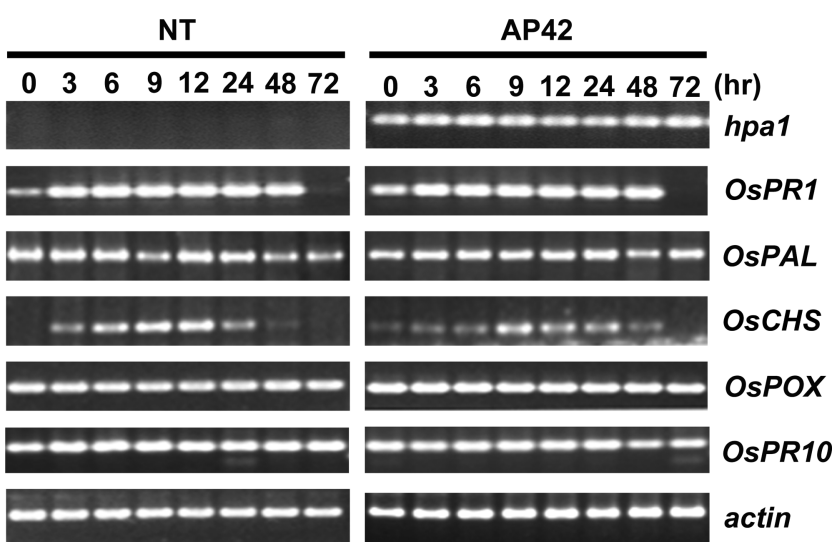

Fig. 4. Expression of defense-related genes in transgenic rice (AP42), compared to that in the non-transformed rice (NT) at the indicated time points after inoculation of $X$. oryzae pv. oryzae strain KXO18 by RT-PCR. Actin gene was used as an internal control. 
Table 3. Locus numbers of rice genes that are up-regulated by treatment of $X$. oryzae pv. oryzae strain KXO18 in AP42 T0 transgenic rice, compared to the wild type rice

\begin{tabular}{clc}
\hline \hline Locus \# & Homologous genes or proteins & Fold change \\
\hline NIAB5210 & Oryza sativa 1-aminocyclopropane-1-carboxylate synthase (OsACS1) & 5.19 \\
NIAB3303 & Zea mays thiamine biosynthetic enzyme (thi1-1) & 4.95 \\
NIAB2023 & Arabidopsis thaliana At5g40630 & 4.43 \\
NIAB2343 & Nicotiana sylvestris chloroplast 29 kD ribonucleoprotein & 4.25 \\
NIAB2262 & Arabidopsis thaliana putative sorbitol dehydrogenase (At5g51970) & 4.12 \\
NIAB2208 & Arabidopsis thaliana At1g54320 & 4.06 \\
NIAB0534 & Zea mays tonoplast membrane integral protein ZmTIP4-2 & 3.65 \\
NIAB4320 & Arabidopsis thaliana At2g16590 & 3.49 \\
NIAB3529 & Arabidopsis thaliana putative arginine/serine-rich protein (At1g16610) & 3.43 \\
NIAB5211 & Oryza sativa Ran & 3.33 \\
NIAB2097 & Arabidopsis thaliana At5g25754 & 3.24 \\
NIAB0219 & Oryza sativa glycine-rich protein $($ Os GRP1) & 3.11 \\
\hline
\end{tabular}

responsible for Hpa1-mediated disease resistance in rice, five of previously known defense-related genes, OsPR1, OsPAL, OsCHS, OsPOX, and OsPR10 were checked by RT-PCR in transgenic rice before and after inoculation with $X$. oryzae pv. oryzae strain KXO18. Although PRl and $O s C H S$ genes looked more expressed in transgenic rice than in the non-transformed plant at $0 \mathrm{hr}$, none of them showed any significant difference in gene expression (Fig. 4).

In order to examine any genes that are up- or downregulated after inoculation with $X$. oryzae pv. oryzae strain KXO18, we performed microarray experiment with a DNA chip carrying 5,000 random rice genes. From this analysis, at least 12 up-regulated genes, which were shown over 3fold difference, were found, compared to those in the wild type rice plants (Table 3 ). All of them except OsACS1 gene, which showed the highest induction level, did not show strong connection to disease resistance. Therefore, expression pattern of OsACS1 gene after inoculation with $X$. oryzae pv. oryzae strain KXO18 was determined. Consistent with microarray data, its expression was induced about 3 hrs after inoculation in the transgenic rice plant, compared to about $24 \mathrm{hrs}$ in the non-transformed rice plant (Fig. 5). ACS1 gene encodes 1-aminocyclopropane-1-carboxylate synthase (ACC synthase), which is known as a critical enzyme for ethylene biosynthesis in plants, and five $A C S$ genes are present as a multigene family in rice (Zarembinski and Theologis, 1997). These results indicate that ethylenemediated pathway might be involved in Hpa1-mediated disease resistance.

The relationship between harpin function and ethylenemediated pathway has been reported in diverse plant species, including tomato and Arabidopsis. By microarray analysis in tomato, expression of SlERF1 gene encoding ethyleneresponse factor 5 was shown to be induced to the highest level, when HrpN of E. amylovora was treated (Chuang et

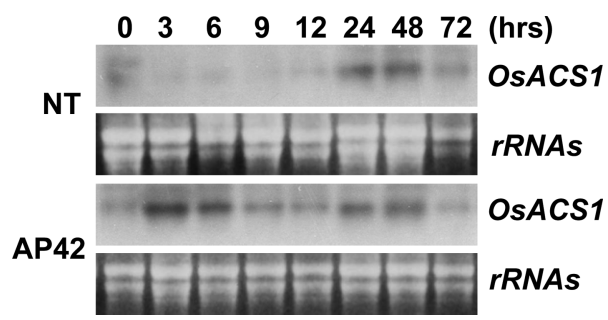

Fig. 5. Expression of rice $O S A C S 1$ gene, encoding 1-aminocyclopropane-1 carboxylate synthase in transgenic rice. Rice transgenic plants (AP42) were inoculated with X. oryzae pv. oryzae strain KXO18, and leaves were collected at the designated time points after pathogen inoculation, and northern blot analysis was carried out with the indicated genes as probes. Ribosomal RNAs (rRNAs) were shown by ethidium bromide staining as loading controls. NT, non-transformed.

al., 2010). In addition, treatment with the same harpin in Arabidopsis increases ethylene level, and the ethylene receptor gene ETR 1 was required for harpin-induced plant growth enhancement and insect resistance because these effects were impaired in the etrl-1 mutant (Dong et al., 2004). Recently, transcriptome profiling was carried out in cotton carrying hpal gene, and it showed that expression of genes involved in multiple defense signaling pathways, including and ethylene-mediated defense pathways, was induced (Miao et al., 2010).

\section{Acknowledgments}

We thank Dr. Nam-Soo Jwa and Dr. Ju-Kon Kim for providing pCAM-p35S::GFP and pSBG-MAR vectors, respectively. This work was supported by grant from the National Research Foundation of Korea funded by the Korean Government to Min-Seon Choi and Chang-Sik Oh (NRF-2012-0003305). 


\section{References}

Ahn, I. P., Kim, S., Kang, S., Suh, S. C. and Lee, Y. H. 2005a. Rice defense mechanisms against Cochliobolus miyabeanus and Magnaporthe grisea are distinct. Phytopathology 95: $1248-1255$.

Ahn, I. P., Kim, S. and Lee, Y. H. 2005b. Vitamin B1 functions as an activator of plant disease resistance. Plant Physiol. 138:1505-1515.

Alfano, J. R. and Collmer, A. 1997. The type III (Hrp) secretion pathway of plant pathogenic bacteria: trafficking harpins, Avr proteins, and death. J. Bacteriol. 179:5655-5662.

Arlat, M., Van Gijsegem, F., Huet, J. C., Pernollet, J. C. and Boucher, C. A. 1994. PopA1, a protein which induces a hypersensitivity-like response on specific Petunia genotypes, is secreted via the Hrp pathway of Pseudomonas solanacearum. EMBO J. 13:543-553.

Beer, S. V., Wei, Z. M., Laby, R. J., He, S. Y., Bauer, D. W., Collmer, A. and Zumoff, C. 1993. Are harpins universal elicitors of the hypersensitive response of phytopathogenic bacteria? In Advances in molecular genetics of plant-microbe intractions, (ed. E. N. Nester and D. P. S. Verma), pp. 281-286. Dordrecht, The Netherlands: Kluwer Academic Publishers.

Boyes, D. C., Zayed, A. M., Ascenzi, R., McCaskill, A. J., Hoffman, N. E., Davis, K. R. and Gorlach, J. 2001. Growth stagebased phenotypic analysis of Arabidopsis: a model for high throughput functional genomics in plants. Plant Cell 13:14991510 .

Cao, H., Bowling, S. A., Gordon, A. S. and Dong, X. 1994. Characterization of an Arabidopsis mutant that is nonresponsive to inducers of systemic acquired resistance. Plant Cell 6:15831592.

Charkowski, A. O., Alfano, J. R., Preston, G., Yuan, J., He, S. Y. and Collmer, A. 1998. The Pseudomonas syringae pv. tomato HrpW protein has domains similar to harpins and pectate lyases and can elicit the plant hypersensitive response and bind to pectate. J. Bacteriol. 180:5211-5217.

Chuang, H., Harnrak, A., Chen, Y.-C. and Hsu, C.-M. 2010. A harpin-induced ethylene-responsive factor regulates plant growth and responses to biotic and abiotic stresses. Biochem. Biophys. Res. Commun. 402:414-420.

Clough, S. J. and Bent, A. F. 1998. Floral dip: a simplified method for Agrobacterium-mediated transformation of Arabidopsis thaliana. Plant J. 16:735-743.

Delaney, T. P., Friedrich, L. and Ryals, J. A. 1995. Arabidopsis signal transduction mutant defective in chemically and biologically induced disease resistance. Proc. Natl. Acad. Sci. USA 95:6602-6606.

Dong, H., Delaney, T. P., Bauer, D. W. and Beer, S. V. 1999. Harpin induces disease resistance in Arabidopsis through the systemic acquired resistance pathway mediated by salicylic acid and the NIM1 gene. Plant J. 20:207-215.

Dong, H. P., Peng, J., Bao, Z., Meng, X., Bonasera, J. M., Chen, G., Beer, S. V. and Dong, H. 2004. Downstream divergence of the ethylene signaling pathway for harpin-stimulated Arabidopsis growth and insect defense. Plant Physiol. 136:3628-
3638.

Durrant, W. E. and Dong, X. 2004. Systemic acquired resistance. Annu. Rev. Phytopathol. 42:185-209.

Hammond-Kosack, K. E. and Parker, J. E. 2003. Deciphering plant-pathogen communication: fresh perspectives for molecular resistance breeding. Curr. Opin. Biotechnol. 14:177-193.

He, S. Y., Huang, H.-C. and Collmer, A. 1993. Pseudomonas syringae pv. syringae harpin ${ }_{\mathrm{Ps}}$ : a protein that is secreted via the Hrp pathway and elicits the hypersensitive response in plants. Cell 73:1255-1266.

Hiei, Y., Ohta, S., Komari, T. and Kumashiro, T. 1994. Efficient transformation of rice (Oryza sativa L.) mediated by Agrobacterium and sequence analysis of the boundaries of the T-DNA. Plant J. 6:271-282.

International Network for Genetic Evaluation of Rice and International Rice Research Institute. 1996. Standard evaluation system for rice. $4^{\text {th }}$ ed. International Rice Research Institute, Manila, Philippines. 18 pp.

Ji, Z., Song, C., Lu, X. and Wang, J. 2011. Two coiled-coil regions of Xanthomonas oryzae pv. oryzae harpin differ in oligomerization and hypersensitive response induction. Amino Acids 40:381-392.

Keen, N. T. 1990. Gene-for-gene complementarity in plant-pathogen interactions. Annu. Rev. Genet. 24:447-463.

Kim, J. F. and Beer, S. V. 1998. HrpW of Erwinia amylovora, a new harpin that contains a domain homologous to pectate lyases of a distinct class. J. Bacteriol. 180:5203-5210.

Kim, J. G., Park, B. K., Yoo, C. H., Jeon, E., Oh, J. and Hwang, I. 2003. Characterization of the Xanthomonas axonopodis pv. glycines Hrp pathogenicity island. J. Bacteriol. 185:31553166.

Koh, Y. J., Hwang, B. K. and Chung, H. S. 1987. Adult-plant resistance of rice to leaf blast. Phytopathology 77:232-236.

Kvitko, B. H., Ramos, A. R., Morello, J. E., Oh, H.-S. and Collmer, A. 2007. Identification of harpins in Pseudomonas syringae pv. tomato DC3000, which are functionally similar to HrpK1 in promoting translocation of type III secretion system effectors. J. Bacteriol. 189:8059-8072.

McElroy, D., Zhang, W., Cao, J. and Wu, R. 1990. Isolation of an efficient actin promoter for use in rice transformation. Plant Cell 2:163-171.

Miao, W., Wang, X., Song, C., Wang, Y., Ren, Y. and Wang, J. 2010. Transcriptome analysis of $\mathrm{Hpal}_{\mathrm{Xoo}}$ transformed cotton revealed constitutive expression of genes in multiple signaling pathways related to disease resistance. J. Exp. Bot. 61:42634275.

Noel, L., Thieme, F., Nennstiel, D. and Bonas, U. 2002. Two novel type III-secreted proteins of Xanthomonas campestris pv. vesicatoria are encoded within the hrp pathogenicity island. J. Bacteriol. 184:1340-1348.

Peng, J. L., Bao, Z. L., Ren, H. Y., Wang, J. S. and Dong, H. S. 2004. Expression of harpin(xoo) in transgenic tobacco induces pathogen defense in the absence of hypersensitive cell death. Phytopathology 94:1048-1055.

Perino, C., Gaudriault, S., Vian, B. and Barny, M. A. 1999. Visualization of harpin secretion in planta during infection of apple 
seedlings by Erwinia amylovora. Cell Microbiol. 1:131-141.

Reymond, P., Weber, H., Damond, M. and Farmer, E. E. 2000. Differential gene expression in response to mechanical wounding and insect feeding in Arabidopsis. Plant Cell 12:707-720.

Thomma, B. P. H. J., Eggermont, K., Penninckz, I. A. M. A., Mauch-Mani, B., Vogelsang, R., Cammue, B. P. A. and Broekaert, W. F. 1998. Separate jasmonate-dependent and salicylate-dependent defense response pathways in Arabidopsis are essential for resistance to distinct microbial pathogens. Proc. Natl. Acad. Sci. USA 95:15107-15111.

Thomma, B. P. H. J., Eggermont, K., Tierens, K. F. M.-J. and Broekaert, W. F. 1999. Requirement of functional EIN2 (ethylene insensitive 2) gene for efficient resistance of Arabidopsis thaliana to infection by Botrytis cinerea. Plant Physiol. 121:1093-1101.

Wei, Z. M., Laby, R. J., Zumoff, C. H., Bauer, D. W., He, S. Y., Collmer, A. and Beer, S. V. 1992. Harpin, elicitor of the hypersensitive response produced by the plant pathogen Erwinia amylovora. Science 257:85-88.

Zarembinski, T. I. and Theologis, A. 1997. Expression characteristics of $O s-A C S 1$ and $O s-A C S 2$, two members of the 1-aminocyclopropane-1-carboxylate synthase gene family in rice (Oryza sativa L. cv. Habiganj Aman II) during partial submergence. Plant Mol. Biol. 33:71-77.

Zhu, W., MaGbanua, M. M. and White, F. F. 2000. Identification of two novel $h r p$-associated genes in the hrp gene cluster of Xanthomonas oryzae pv. oryzae. J. Bacteriol. 182:1844-1853. 